\title{
THE ROLE OF A TEACHER IN THE UPBRINGING OF PROFESSIONAL AND PERSONAL QUALITIES OF STUDENTS
}

\section{L.D. Boreyko, S.B. Semenenko, I.R. Tymofiychuk, X.V. Slobodian}

HSEE of Ukraine "Bukovinian state medical university", Chernivtsi

\author{
Key words: \\ upbringing, \\ student, teacher, \\ curator. \\ Clinical and \\ experimental \\ pathology. Vol.16, \\ №4 (62). P.125-128. \\ DOI:10.24061/1727- \\ 4338.XVI.4.62.2017.66 \\ E-mail: \\ semenenko.svitlana@ \\ bsmu.edu.ua
}

Objective - the purpose of the work is to analyze the role of the teacher in the education of the professional and personal qualities of students.

Material and methods. The role of a teacher in upbringing a future doctor, as a creative person and a professional specialist is very important in the labor market. The problem of a valuable relationship to the world, the functioning of valuable orientations in the work of the doctor plays an important role, therefore it is extremely necessary to develop in the students motivations and values of the personality of the doctor, the ability to creative, systemic application of knowledge in solving professional theoretical and practical tasks. Results. The education of a student as a specialist is focused on the development of deep interest, love for the chosen profession, professional self-awareness, responsibility, ability to set creative and effectively solve professional tasks in the field of medicine, readiness to make non-standard decisions; openness to new achievements of science and practice. The personality of the teacher, especially in the disciplines of professional orientation, plays an important role in this process.

Conclusion. The curator is the organizer of the students' activity and the coordinator of educational activities. His role is to create conditions that would help the student to find himself and his place in the student community and in social life. Collaboration between a teacher and a student contributes to the goal of vocational training through the formation of love and responsible attitude towards the chosen profession, the formation of the basis of the professional skills.

\section{Ключевые слова: воспитание, студент, преподаватель, куратор.}

Клиническая и экспериментальная патология Т.16, №4 (62). С.125-128.

\section{РОЛЬ ПРЕПОДАВАТЕЛЯ В ВОСПИТАНИИ ПРОФЕССИОНАЛЬНО-ЛИЧНОСТНЫХ КАЧЕСТВ СТУДЕНТОВ}

\section{Л.Д. Борейко, С.Б. Семененко И.Р. Тимофийчук, К.В. Слободян}

Цель работы - проанализировать роль преподавателя в воспитании профессионально-личностных качеств студентов. Материал и методы. Роль преподавателя в воспитании будущцого врача, как творческой личности и профессионального специиалиста, имеет большое значение на рынке труда. Проблема ценностного отношения кмиру, функционирование ценностных ориентаций в работе врача занимает важное место, поэтому очень необходимо развивать у студентов соответственные мотивации и ценности личности врача, навычки к креативному, системному применению знаний в развязывании профессиональных теоретических и практических заданий. Результаты. Воспитание студента как специалиста ориентированно на развитие глубокой заинтересованности, любви к избранной профессии, профессиональному самосознанию, эрудиции и компетенции; осознании профессионального интереса и ответственности, умении ставить творческие и эффективно развязывать профессиональныле задачи в отрасли медицины, готовности принимать нестандартные решения; открытости к новым досятижениям науки и практики. Важную роль в этом процессе занимает личность преподавателя, 6 частности, дисциплин профессиональной ориентации. Вывод. Куратор есть организатором деятельности студента и координатором воспитательных действий. Его роль заключается в создании таких условий, которые помогли бы студенту найти себя и свое место в студенческом коллективе и в социальной жизни. Сотрудничество между преподавателем и студентом способствует реализации иели профессиональной подготовки путем формирования любви и ответственного отношения к избранной профессии, формирования основ профессионального мастерства.

\section{РОЛЬ ВИКЛАДАЧА У ВИХОВАННІ ПРОФЕСІЙНО-ОСОБИСТІСНИХ ЯКОСТЕЙ СТУДЕНТІВ}

\section{Л.Д. Борейко, С.Б. Семененко І.Р. Тимофійчук, К.В. Слободян}

Мета роботи - проаналізувати роль викладача у вихованні професійно-особистісних якостей студентів. 
Матеріал і методи. Роль викладача у вихованні майбутнього лікаря як творчої особистості і професійного спеціаліста має велике значення на ринку праџі. Проблема цінного відношення до світу, функціонування цінних орієнтацій в роботі лікаря займає важливе місие, тому вкрай необхідно розвивати у студентів відповідні мотивації і ичінності особистості лікаря, здібності до креативного, системного застосування знань у розв'язанні професійних теоретичних $i$ практичних завдань. Результати. Виховання студента як спеціаліста орієнтовано на розвиток глибокої зачікавленості, любові до вибраної професії, професійного самоусвідомлення, відповідальності, умінні ставити творчі і ефективно розв'язувати професійні завдання в галузі медицини, готовності приймати нестандартні рішення; відкритості до нових досягнень науки і практики. Важливу роль у цььому процесі займає особистість викладача, особливо з дисичилін професійної орієнтаüiï.

Висновок. Куратор є організатором діяльності студента і координатором виховних дій. Його роль полягає у створенні таких умов, які б допомогли студенту знайти себе і своє місие в студентському колективі і в соціальному житті. Співпраця між викладачем та студентом сприяє реалізації мети професійної підготовки шляхом формування любові та відповідального відношення до вибраної професії, формування основ професійної майстерності.
Ключові слова:

виховання,

студент,

викладач,

куратор.

Клінічна та експериментальна патологія Т.16, №4 (62). C.125-128.

\section{Introduction}

The modern period of study at a higher educational establishment is the fateful years that a young person educates, her spirituality, her civic position, ethical and moral orientations, and the common culture.

Educational work with students is an integral part of vocational and pedagogical activity of a teacher of a higher educational institution, and therefore it reveals the creative search for a teacher, his individual uniqueness, and professional orientation for the formation of a modern competent specialist [5].

This can only be achieved if a comprehensive approach is taken and the entire university professorial staff, administration, and student self-government bodies are involved in this work. A modern specialist should not only adapt to the rapid social changes, but also be able practically to evaluate what is happening and outline the ways of further transformations in the field of activity and in their lives. Since the personality of a student in a higher educational institution is the object of education, its formation must be carried out both through the consciousness and the inner world of this person, and through the environment in which it is located [7,8].

\section{Objective}

The purpose of the work is to analyze the role of the teacher in the education of the professional and personal qualities of students.

\section{Main part}

Educational work is a special and difficult task, the solution of which requires on the one hand, the search and commissioning of new forms of influence on students, the development of new techniques and on the other hand - the activation of traditional activities, the preservation of achievements of the past. Accordingly, the main directions of work can be distinguished: humanization of education, national patriotic education, artistic and aesthetic education, physical culture, mass media and popularization work, social and everyday spheres $[3,6]$. Possession of

ISSN 1727-4338 https://www.bsmu.edu.ua psychological, pedagogical, creative, professional and other no less important qualities of the modern specialist of medicine is an integral feature. Performing any professional functions a person always realizes himself as a person. Education is one of the factors influenced by human development. After all, it is when the medical specialist starts his practical activity he must have all the professional qualities that will facilitate his collaboration with patients, staff and colleagues.

The education of a student as a specialist is focused on the development of deep interest, love for the chosen profession, professional self awareness, erudition and competence; awareness of professional interest and responsibility, the ability to put creative and efficiently solve professional tasks in the field of medicine, readiness to make non-standard decisions; openness for new achievements of science and practice [4].

An important role in this process is played by the personality of the teacher, especially the disciplines of professional orientation. The education of a student as a creative individual involves the development of methodological, research culture; creativity-search skills and abilities, abilities both for individual and collective creativity in the chosen sphere of professional activity; abilities to creative, systematic application of knowledge in solving professional theoretical and practical tasks [2].

The essence of professional education is the formation of a student as an expert. It is therefore essential to combine theory and practice with the greatest efficiency to pass on students the necessary amount of knowledge and ability, to teach them systematically to work on themselves, to use the acquired knowledge in the realities of the present. Lectures, practical classes, meetings with specialists, self study classes, preparation of research works far from the complete list of forms of work on the path of professional formation of young scientists. One of the components of professional development is the acquisition of knowledge and skills of working with people, psychological readiness to work in market conditions and to answer for the results of their work. 
To help the student to adapt to the conditions and requirements of university education, to study and organize educational and non-educational activities can be the curator of the group [1]. After all, the most important directions of activity of the curators is the adaptation of the freshmen to the new conditions of studying. Assistance to students in solving their social and domestic problems and leisure activities; assistance in forming the atmosphere of friendship, benevolence, cohesion and mutual support in the student group, in the awareness of its involvement in the university community of teachers and employees, united by one organizational culture a system of views and values $[3,2]$. One of the main tasks of the system of educational work in the group of students is planning, which is the development of a system of measures aimed at achieving the goal, tasks of national, civic and patriotic education of student youth [7].

The activities of the curator of the group of students include the following: familiarization with a group of students; visiting dormitories, cooperation with student councils of dormitories in order to improve the living conditions of students, collecting information about each student; Identification of creative and gifted students through testing, questioning, observation, conversation, method of expert evaluations; discussion of issues of success and discipline, manuals; organization of consultations; relationship with teachers, individual work; meetings with veterans of work; excursion work; participation in sports competitions of faculty, university; participation in general-university events, amateur performances; development of programs of individual development and self-development of the student's creative personality; recommendations on the organization of educational and non-auditing activities; promotion of the development and formation of positive features as well as self-criticism, writing reports for the academic year.

The group's curators attend lectures, practical classes on various disciplines taught in the group, facilitate the organization of additional consultations on the eve of modular controls; discuss the state of progress and production discipline on a monthly basis in educational hours; follow the timely completion of individual plans for students in their group. Exploratory work is being carried out on the negative consequences of untimely completion of modules, skilled advice is provided in solving problems that have led to the accumulation of academic debt, carried out with joint control with the Dean's Office.

\section{Conclusion}

The curator is the organizer of the student's activity and the coordinator of educational activities. His role is to create conditions that would help the student to find himself and his place in the student community and in social life. Collaboration between a teacher and a student contributes to the goal of vocational training through the formation of love and responsible.

\section{Список літератури}

1.Алексєєва ОВ. Формування громадянської позиції сучасної молоді. Педагогіка і психологія. Вісник Академії педагогічних наук України. 2006;2:31-5.

2.Вітвицька СС. Основи педагогіки вищої школи. Підручник за модульно-рейтинговою системою навчання для студентів магістратури. Київ: Центр навчальної літератури; 2003. 384 с.

3.Желябіна НК, редактор. Інноваційні комунікативні технології в роботі куратора академічної групи: метод. реком. Запоріжжя: ЗДІА; 2007. 67 с.

4.Козловська IM. Проблема підготовки фахівця у контексті основних філософських категорій: наук.-метод. реком. Львів: Сполом; 2006. $16 \mathrm{c}$

5.Матвіїшин ЛП. Роль куратора групи в організації навчально-виховного процесу. Клінічна та експериментальна патологія. 2011;10(3):34-7.

6.Мойсеюк НС. Готовність до професійної діяльності: суть шляхи формування. В: Зязюн IA, редактор. Збірник наукових праць Сучасні інформаційні технології та інноваційні методики навчання у підготовці фахівців: методологія, теорія, досвід, проблеми. 2006;12:364-8.

7.Тихонова ОО. Про важливість ролі куратора у формуванні професійної компетентності студентів-медиків. Вісник проблем біології і медицини. 2013;3:70-3.

8.Сімахіна ГО. Особистість, освячена добром. В: Науковометодичний збірник. Спеціальний випуск. Матеріали Всеукр. наук.-метод. конф. Виховна робота у вищому навчальному закладі - невід'ємна складова підготовки висококваліфікованих фахівців: традиції та новаторство; 2013 Лис 21; Київ. Київ: НУХТ; 2013, с. 13

References

1.Aleksieieva OV. Formuvannia hromadians'koi pozytsii suchasnoi molodi [Formation of civic attitudes of modern youth]. Pedahohika i psykholohiia. Visnyk Akademii pedahohichnykh nauk Ukrainy. 2006;2:31-5. (in Ukrainian).

2.Vitvyts'ka SC. Osnovy pedahohiky vyschoi shkoly [Fundamentals of higher education pedagogy]. Pidruchnyk za modul'noreitynhovoiu systemoiu navchannia dlia studentiv mahistratury. Kyiv: Tsentr navchal'noi literatury; 2003. 384 s. (in Ukrainian).

3.Zheliabina NK, redaktor. Innovatsiini komunikatyvni tekhnolohii $\mathrm{v}$ roboti kuratora akademichnoi hrupy [Innovative communicative technologies in the work of curator of the academic group]: metod. rekom. Zaporizhzhia: ZDIA; 2007. 67 s. (in Ukrainian).

4.Kozlovs'ka IM. Problema pidhotovky fakhivtsia u konteksti osnovnykh filosofs'kykh katehorii [The problem of training a specialist in the context of the main philosophical categories]: nauk.-metod. rekom. L'viv: Spolom; 2006. 16 s. (in Ukrainian).

5.Matviishyn LP. Rol' kuratora hrupy $\mathrm{v}$ orhanizatsii navchal'no-vykhovnoho protsesu [The role of the curator of the group in the organization of the educational process]. Klinichna ta eksperymental'na patolohiia. 2011;10(3):34-7. (in Ukrainian)

6.Moiseiuk NIe. Hotovnist' do profesiinoi diial'nosti: sut' i shliakhy formuvannia [Readiness for professional activity: the essence and ways of formation]. V: Ziaziun IA, redaktor. Zbirnyk naukovykh prats' Suchasni informatsiini tekhnolohii ta innovatsiini metodyky navchannia u pidhotovtsi fakhivtsiv: metodolohiia, teoriia, dosvid, problemy. 2006;12:364-8. (in Ukrainian).

7.Tykhonova OO. Pro vazhlyvist' roli kuratora u formuvanni profesiinoi kompetentnosti studentiv-medykiv [The importance of the role of the curator in shaping the professional competence of medical students]. Visnyk problem biolohii i medytsyny. 2013;3:703. (in Ukrainian).

8. Simakhina HO. Osobystist', osviachena dobrom [Personality blessed with goodness]. V: Naukovo-metodychnyi zbirnyk. Spetsial'nyi vypusk. Materialy Vseukr. nauk.-metod. konf. Vykhovna robota u vyschomu navchal'nomu zakladi - nevid'iemna skladova pidhotovky vysokokvalifikovanykh fakhivtsiv: tradytsii ta novatorstvo; 2013 Lys 21; Kyiv. Kyiv: NUKhT; 2013, s. 13. (in Ukrainian).

Information about authors:

Boreyko L.D. Candidate of Medical Sciences, Associate Professor of the Deportment of Nursing and Higher Nursing Education HSEEU "Bukovinian State Medical University"

Клінічна та експериментальна патологія. 2017. Т.16, №4 (62) ISSN 1727-4338 https://ww.bsmu.edu.ua 
Semenenko S.B. Candidate of Biological Sciences, Associate Professor of the Deportment of Physiology named Ya.D. Kirshenblat HSEEU "Bukovinian State Medical University"

Timofiichuk I.R.. Candidate of Medical Sciences, Associate Professor of the Deportment of Physiology named Ya.D. Kirshenblat HSEEU "Bukovinian State Medical University"

Slobodian X.V. Candidate of Medical Sciences, Associate Professor of the Deportment of Patological Physiology HSEEU

"Bukovinian State Medical University"

\section{Відомості про авторів:}

Борейко Л.Д., кандидат медичних наук, доцент кафедри догляду за хворими та вищої медсестринської освіти ВДНЗ

України "Буковинський державний медичний університет"

Семененко С.Б., кандидат біологічних наук, доцент кафедри фізіології ім. Я.Д. Кіршенблата ВДНЗ України "Буковинський державний медичний університет"

Тимофійчук I.P., кандидат медичних наук, доцент кафедри фізіології ім. Я.Д. Кіршенблата ВДНЗ України "Буковинський державний медичний університет"

Слободян К.В., кандидат медичних наук, доцент кафедри патологічної фізіології ВДНЗ України "Буковинський державний медичний університет"

\section{Сведения об авторах:}

Борейко Л.Д., кандидат медицинских наук, доцент кафедры ухода за больными и высшего медсестринского образования ВГУЗ Украины "Буковинский государственный медицинский университет"

Семененко С.Б., кандидат биологических наук, доцент кафедры физиологии им. Я.Д. Киршенблата ВГУЗ Украины "Буковинский государственный медицинский университет"

Тимофийчук И.Р., кандидат медицинских наук, доцент кафедры физиологии им. Я.Д. Киршенблата ВГУЗ Украины

"Буковинский государственный медицинский университет"

Слободян К.В., кандидат медицинских наук, доцент кафедры патологической физиологии ВГУЗ Украины "Буковинский государственный медицинский университет" 